\title{
Reorganization of Membrane Cholesterol at an Early Stage of Exocytosis (Degranulation) in Rat Mast Cells: Inferred from the Ditribution of Filipin-Cholesterol Comlexes
}

\author{
Takashi Sekiya, Yoshiko Banno and Yoshinori Nozawa \\ Department of Biochemistry, Gifu University School of Medicine, 40 Tsukasa- \\ machi, Gifu 500, Japan
}

\begin{abstract}
Using filipin, a sterol-specific polyene antibiotic, we examined the redistribution of cholesterol molecules present at an early stage of degranulation (release of heparin-protein complexes) in rat peritoneal mast cells with freeze-fracture electron microscopy. Isolated mast cells first were stimulated to undergo degranulation with compound $48 / 80(1 \mu \mathrm{g} / \mathrm{ml})$ for $3 \mathrm{sec}$, then were treated with a glutaraldehyde solution containing filipin $(50 \mu \mathrm{g} / \mathrm{ml})$ for 30 min. Freeze-fractures of the plasma membrane of these cells showed small depressions which lacked filipin-cholesterol complexes. These are the first recognizable membrane alterations and are suggested to correspond to the initial sites of fusion between the plasma and granule membranes. Subsequently, these depressions became bulges. Filipin-cholesterol complexes are absent from the portion of the bulges in close contact with the plasma membrane, probably because the bulges have not yet fused with the underlying granule membrane. These complexes also were absent from the periphery of the two apposed membranes at exocytotic sites during fusion. Even after fusion was complete, no complexes appeared in the circumferential zone where the plasma membrane and the secretory granule membrane had fused. Our results suggest that membrane cholesterol is reorganized at the fusion sites between the plasma and granule membranes during mast cell secretion, and that this alteration in the organization of cholesterol in the plasma membrane represents an initial event during mast cell secretion. A hypothetical model for the sequential changes in the plasma membrane during degranulation is proposed.
\end{abstract}

Membrane fusion, which mediates secretion, is a necessary step in the transfer of the heparin-protein complexes contained within the granules to extracellular space. Secretion of histamine is induced by noncytotoxic agents such as A 23187 (13), compound $48 / 80(2,3,6,14,17,24,26)$, polymyxin $B(4,7,8,17,18)$ and antibodies $(1,19)$. Histamine is stored in the heparin-protein complex released by anion exchange between the histamine in the secretory granules and cations in the extracellular milieu (1). Ultrastructural alterations during degranulation of mast cells have been shown

Abbreviations used: PF, protoplasmic fracture face; EF, exoplasmic fracture face; IMPs, intramembrane particles; BSA, bovine serum albumin; DMSO, dimethyl sulfoxide; SEM, scanning electron microscope. 
by thin section $(1-3,13,17-19,24,26)$, scanning (14) and freeze-fracture $(6-8,19$, 21) electron microscopy. Freeze-fracture studies have revealed that intramembrane particles (IMPs) are absent from the plasma membrane and the altered granule membrane in regions where these membranes appear to be interacting $(8,19,21)$. In contrast, Chandler et al. (6) have demonstrated with quick-freezing that the clearing of IMPs does not occur on either the plasma or granule membrane; localized clearing of IMPs in the two apposed membranes probably is an artifact of glutaraldehyde fixation $(5,29)$.

Membrane sterol is important in maintaining the proper membrane fluidity and is considered a biostabilizer in the membrane (9). Therefore, the distribution of cholesterol should be altered in regions where dynamic membrane events such as fusion take place. To obtain evidence on cholesterol reorganization, the distribution of filipincholesterol complexes in the plasma membrane of mast cells has been examined. Polyene antibiotics have a high specific affinity for sterols $(12,15)$, and form filipinsterol complexes which show up as protuberances or pits in freeze-fracture replicas $(16,23,25,30)$. Thus, the use of this drug yields useful information about the distribution of sterol in the bilayer membrane. Several studies which used freeze-fracture electron microscopy have shown that cholesterol is distributed heterogeneously (10, 20, 21, 22).

In this study, we examined the redistibution of membrane cholesterols at an early stage of degranulation in rat pritoneal mast cells, based on observations of the arrangement of filipin-cholesterol complexes.

\section{MATERIALS AND METHODS}

Preparation of cell suspensions. Twenty male wister rats weighing 200-300 g were decapitated and their mast cells collected by washing the peritoneal cavity with the suspension medium described by Sulivan et al. (28). The medium contained $150 \mathrm{mM} \mathrm{NaCl}, 3.7 \mathrm{mM}$ $\mathrm{Na}_{2} \mathrm{HPO}_{4}, 3.5 \mathrm{mM} \mathrm{KH} \mathrm{PO}_{4}, 0.9 \mathrm{mM} \mathrm{CaCl}, 5.6 \mathrm{mM}$ dextrose, $0.1 \%(\mathrm{w} / \mathrm{v})$ bovine seurm albumin and 10 units $/ \mathrm{ml}$ heparin, $\mathrm{pH}$ 6.8. The opened abdominal cavity was flooded with $15 \mathrm{ml}$ of suspension medium and the trunk of the animal was massaged for $2 \mathrm{~min}$. The pooled cell suspension was centrifuged at $50 \times \mathrm{g}$ for $7 \mathrm{~min}$, after which the supernatant was decanted. The loose cell pellet was resuspended in $2 \mathrm{ml}$ of the suspension medium at $1 \times 10^{7} \mathrm{cells} / \mathrm{ml}$, then the mast cells were purified by centrifugation at room temperature in a BSA density gradient. Two milliliters of the cell suspension was layered over $4 \mathrm{ml}$ of a solution of $38 \%$ BSA $(w / v)$ in the suspension medium in $50 \mathrm{ml}$ poly-carbonate centifuge tubes. Cells were allowed to settle for $25 \mathrm{~min}$, then centrifuged at $450 \times \mathrm{g}$ for $20 \mathrm{~min}$. Mast cells from the pellet were resuspended in the medium at $1 \times 10^{7} \mathrm{cells} / \mathrm{ml}$.

Incubation procedure. Purified mast cells were resuspended in the suspension medium and incubated at $24^{\circ} \mathrm{C}$ for $5 \mathrm{~min}$. Degranulation was induced by adding compound $48 / 80$ (Sigma Chemical Co., St. Louis, Mo.) at a final concentration of $1 \mu \mathrm{g} / \mathrm{ml}$. Incubation was stopped at various times by adding $2 \%$ glutaraldehyde in the same buffer at $24^{\circ} \mathrm{C}$.

Freeze-fracture electron microscopy. The cells were centrifuged after fixation for $10 \mathrm{~min}$, then resuspended for $30 \mathrm{~min}$ in the same fixative containing $50 \mu \mathrm{g} / \mathrm{ml}$ of filipin (Upjohn, Kalamazoo, Mich.) dissolved in dimethyl sulfoxide (DMSO) (final concentration, $0.005 \%$ ). To assess the effects of DMSO on the mast cell membranes, we fixed the control cells in glutaraldehyde with the same concentration of DMSO but without filipin. After the cells had been washed and suspended in fresh $30 \%$ glycerol in $0.85 \% \mathrm{NaCl}$ solution, they were 
pelleted in a clinical centrifuge. The cells then were frozen in Freon-12 and transferred to liquid nitrogen. Samples were fractured at $-110^{\circ} \mathrm{C}$ in a Hitachi $\mathrm{HFZ}-1$ freeze-fracture apparatus. Replicas were cleaned with sodium hypochloride, then rinsed in distilled water, after which they were examined in a JEM-100U electron microscope.

Thin section electron microscopy. Cells were fixed in glutaraldehyde solution at $24^{\circ} \mathrm{C}$ for $10 \mathrm{~min}$. After the cell suspension had been centrifuged, the pellet was fixed with a solution of $4 \%$ glutaraldehyde and $2 \% \mathrm{OsO}_{4}(1: 1)$ in $0.1 \mathrm{M}$ cacodylate buffer for $1 \mathrm{~h}$ then washed in the same buffer. Dehydration was carried out in a graded ethanol series, after which the cells were embedded in Spurr's (27) low viscosity plastic. Thin sections were cut on a Porter-Blum Mt II ultramicrotome, then stained with uranyl acetate and lead citrate and examined in a JEM-100U electron microscope.

Scanning electron microscopy. Resting or stimulated cells initially were fixed in $2 \%$ glutaraldehyde in suspension medium for $10 \mathrm{~min}$. Subsequent fixation used the procedure described for thin sections. The fixed cells were dehydrated through graded concentrations of acetone, then suspended in absolute amyl acetate. Samples that had been dried in a Hitachi HCP-1 critical point drying apparatus, were shadowed with carbon-gold and observed in a JSM-U3 scanning electron microscope.

\section{RESULTS}

Scanning electron microscopy. Resting mast cells showed characteristic surface features in the SEM (Fig. 1a). Cells were approximately spherical, between 6 and 10 $\mu \mathrm{m}$ in diameter with surfaces covered with many microfolds. A small percentage
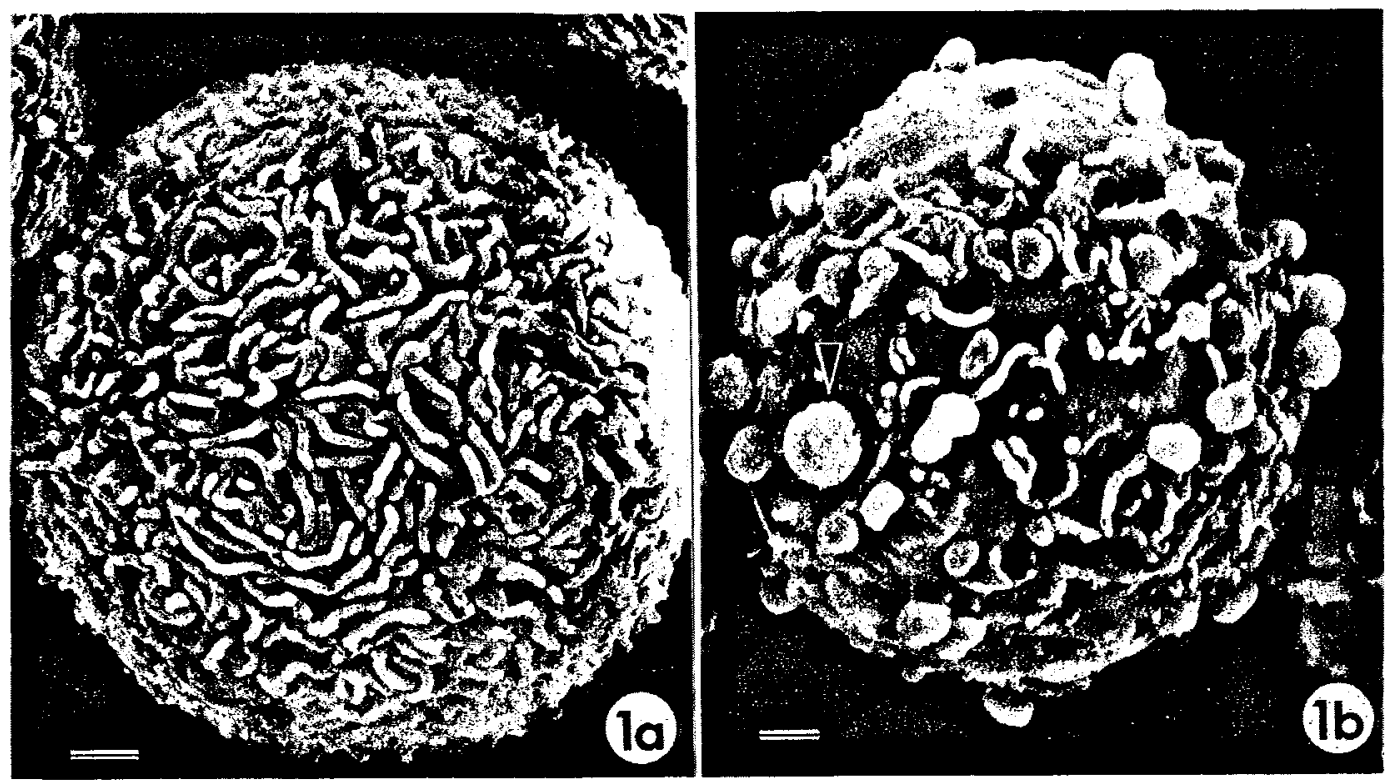

Fig. 1. Scanning electron micrographs of a resting rat mast cell (a) and the same cell stimulated for $10 \mathrm{sec}$ with $1 \mu \mathrm{g} / \mathrm{ml}$ of $48 / 80$ (b). (a) The cell is covered with numerous microfolds of various lengths. (b) A granule is being discharged from an opening site (arrowhead). Other openings also are present on the cell surface. Bar, $1 \mu \mathrm{m}$. 
of the resting cells had numerous mast cell granules visible on their external surfaces. When cells had been stimulated with compound $48 / 80$ for $10 \mathrm{sec}$, however, they showed profound alterations in their surfaces (Fig. 1b). Numerous granules were exposed on the cell surface and the number of microfolds was markedly reduced. Circular openings of various sizes also were frequent on the surface of stimulated cells. Many granules can be seen protruding from the cell surface in Fig. 1b, and one appears to be in the process of being released into the extracellular space through an opening (arrowhead).

Freeze-fracture electron microscopy. In resting mast cells, IMPs 7-12 $\mathrm{nm}$ in diameter were randomly distributed on both the PF and EF faces of the plasma membrane. Numerous microfolds were visible on the fractured plasma membrane. IMPs were more dense on the EF face than on the PF face of the granule membranes, and membrane particles sometimes were distributed irregularly.

When the cells had been stimulated with a noncytotoxic agent for $3 \mathrm{sec}$, then incubated in a glutaraldehyde solution containing filipin, $25-30 \mathrm{~nm}$ protuberances characteristic of filipin-cholesterol complexes were produced on the PF faces of both the plasma and granule membranes. At the same time, small invaginations (70-100 nm diam.), which we call depressions, occasionally were observed on the PF face of the plasma membrane. Filipin-cholesterol complexes clearly lack these depression areas (200-300 nm diam., Fig. 2 and Fig. 8 b).

When mast cells were examined $10 \mathrm{sec}$ after exposure to the releaser, the complexfree areas had become larger and flat $(500-1,200 \mathrm{~nm}$ diam., Fig. 3a, b). In addition, we often observed that bulges, thought to be granule extrusion-related sites, were present close to or attached to peripheral secretory granule membranes. These extrusions were scarcely labelled with filipin (Fig. 4, 8c). On the extrusion membrane PF

Fig. 2. Freeze-fracture image of a mast cell stimulated for $3 \mathrm{sec}$ with $1 \mu \mathrm{g} / \mathrm{ml}$ of $48 / 80$, then incubated in filipin-containing $(50 \mu \mathrm{g} / \mathrm{ml})$ glutaraldehyde solution. Filipin-cholesterol complexes are absent from the small depression areas (200-300 $\mathrm{nm}$ dia.) on the PF face of the plasma membrane. Bar, $0.5 \mu \mathrm{m}$.

Fig. 3. Freeze-fracture images of mast cells stimulated for $10 \mathrm{sec}$ with $1 \mu \mathrm{g} / \mathrm{ml}$ of $48 / 80$, then incubated in filipin-containing $(50 \mu \mathrm{g} / \mathrm{ml})$ glutaraldehyde solution. (a) A small number of large filipin-cholesterol complex - free areas are present on the EF face of the plasma membrane. (b) The large filipin-cholesterol complex-free area appears on the PF face of the plasma membrane. Bar, $0.5 \mu \mathrm{m}$.

Fig. 4. Freeze-fracture image of a mast cell stimulated for $10 \mathrm{sec}$ with $1 \mu \mathrm{g} / \mathrm{ml}$ of $48 / 80$, then incubated in filipin-containing $(50 \mu \mathrm{g} / \mathrm{ml})$ glutaraldehyde solution. Filipin-cholesterol complexes are absent from the bulge on the PF face of the plasma membrane, where IMPs are evenly distributed. The presence of filipin-cholesterol complexes on the EF face of the underlying secretory granular membrane can be seen through a window-like opening in the plasma membrane (arrowhead). Bar, $0.5 \mu \mathrm{m}$.

Fig. 5. Freeze-fracture images of mast cell stimulated for $10 \mathrm{sec}$ with $1 \mu \mathrm{g} / \mathrm{ml}$ of $48 / 80$ (a), then incubated in filipin-containing $(50 \mu \mathrm{g} / \mathrm{ml})$ glutaraldehyde solution (b). (a) Circular folding is seen on the PF face of the plasma membrane, where IMPs are distributed evenly. (b) Filipin-cholesterol complexes are absent from the circular folding of the plasma membrane (EF), but the plasma membrane (PM) and secretory granule membrane (GM) in the area surrounded by the folding are densely labelled with filipin-cholesterol complexes. In some parts of the circular, complex-free area, granule membranes are fused with the plasma membrane (arrowhead). PM: plasma membrane, GM: granule membrane. Bar, $0.5 \mu \mathrm{m}$.

Fig. 6. Freeze-fracture images of mast cells stimulated for $10 \mathrm{sec}$ with $1 \mu \mathrm{g} / \mathrm{ml}$ of $48 / 80$, then incubated in filipin-containing $(50 \mu \mathrm{g} / \mathrm{ml})$ glutaraldehyde solution (a), and a resting mast cell incubated in filipin-containing $(50 \mu \mathrm{g} / \mathrm{ml})$ glutaraldehyde solution (b). (a) The peripheral portion of the circle lacks filipin-cholesterol complexes on the PF face of the plasma membrane. (b) Filipin-cholesterol complexes are distributed randomly on both the plasma (PF) and granule membranes (EF), but they are more dense on the granule membrane than on the plasma membrane. Bar, $0.5 \mu \mathrm{m}$. 
face, IMPs were distributed evenly and randomly. Circular folding of the plasma membrane (700-1,000 nm diam., Fig. 5a, b) took place with cells stimulated for 10 sec. Peripheral granule membranes appear to be fused with the plasma membrane at the site indicated by the arrowhead (Fig. 5b). It should be pointed out that these foldings lacked filipin-cholesterol complexes almost completely, although these complexes were abundant in both the plasma and granule membranes in the region surrounded by the folding. Where degranulation had been completed, circular membrane portions labelled densely with filipin were frequent, but the circumferential zone

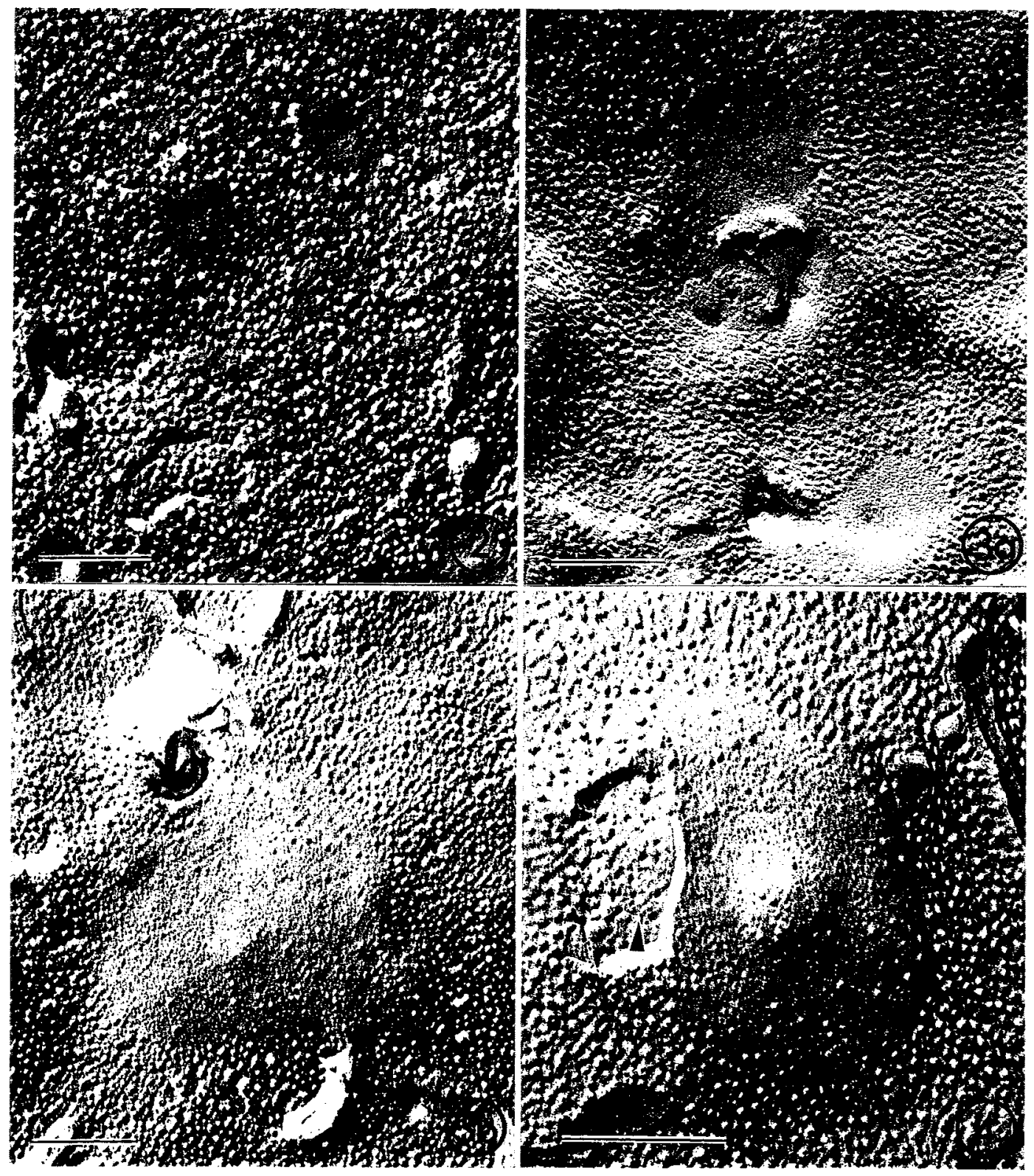


around the circles almost completely lacked filipin-cholesterol complexes (Fig. 6a). These circular areas may correspond to the granule membranes, because they are covered with filipin-cholesterol complexes of as high a density as in the granule membrane (Fig. 6b).

Thin section electron microscopy. Thin section electron microscopy revealed a series of ultrastructural changes in the interaction between the plasma and secretory granule membranes during degranulation of the mast cells. Resting mast cells showed the known ultrastructure described earlier $(1-3,13,17-19,24,26)$. All granules
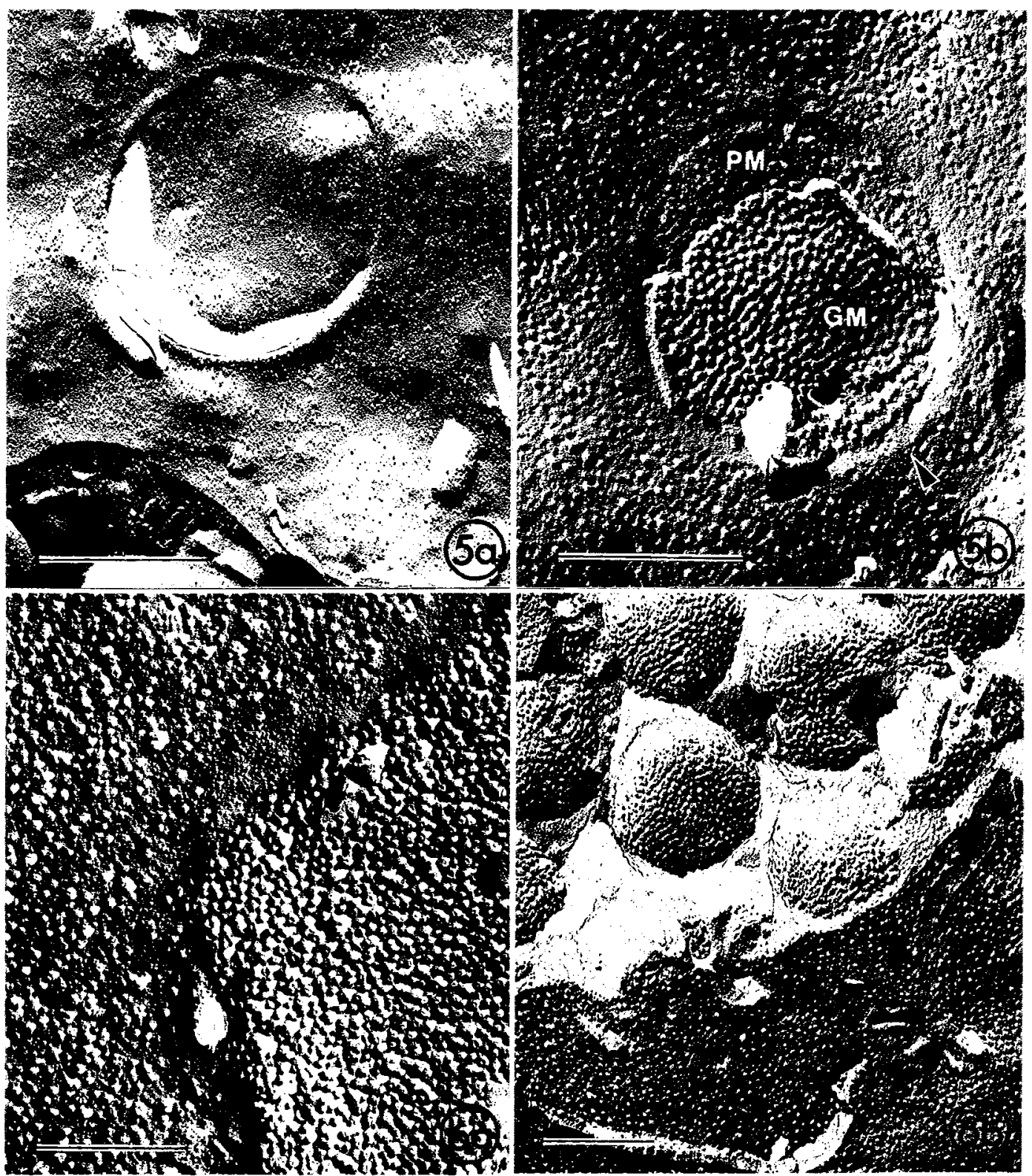
were oval or round (400-1,200 $\mathrm{nm}$ diam.) and were electron dense (Fig. 7a). When mast cells were treated with compound $48 / 80(1 \mu \mathrm{g} / \mathrm{ml})$ for $10 \mathrm{sec}$, the secretory granules showed a decrease in electron density and became somewhat swollen in comparison to normal granules. Vesicles containing granules frequently were seen close to the plasma membrane, so that the cytoplasm sandwiched between the granule and plasma membranes appeared to be a bridge over the vesicle in thin sections.

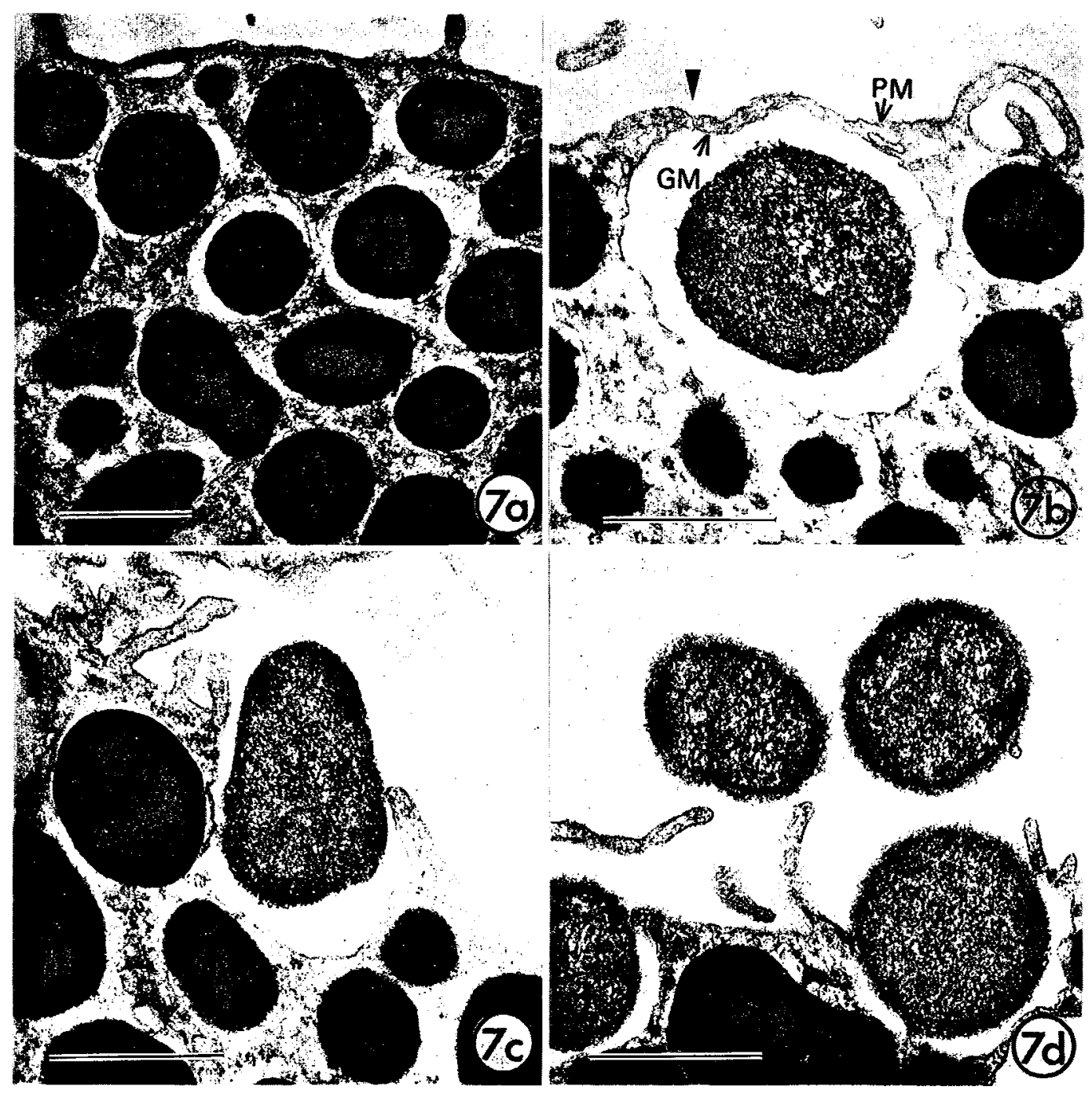

Fig. 7. Thin section micrographs of a resting mast cell (a), the same cell after stimulation for 10 sec with $1 \mu \mathrm{g} / \mathrm{ml}$ of $48 / 80$ (b-d). (a) Electron dense granules in the cytoplasm and are surrounded by granular membranes. (b) The secretory granule shows decreased electron density and has become somewhat swollen. The granule membrane is close to the plasma membrane where the two fuse (arrowhead). (c) A secretory granule is being released into the extracellular milieu. (d) Granules lacking surrounding membrane are present in the extracellular space. PM: plasma membrane, GM: granule membrane, Bar: $0.5 \mu \mathrm{m}$. 
The site of fusion of the plasma membrane with the granule membrane was clear (Fig. 7b). After these membranes had fused, granules were discharged from the opening site (Fig. 7c). Sectioned granules found in the extracellular milieu (Fig. 7d) usually showed poor contrast. In some cells, numerous granules of apparently low electron density were seen deeper within the cytoplasm.

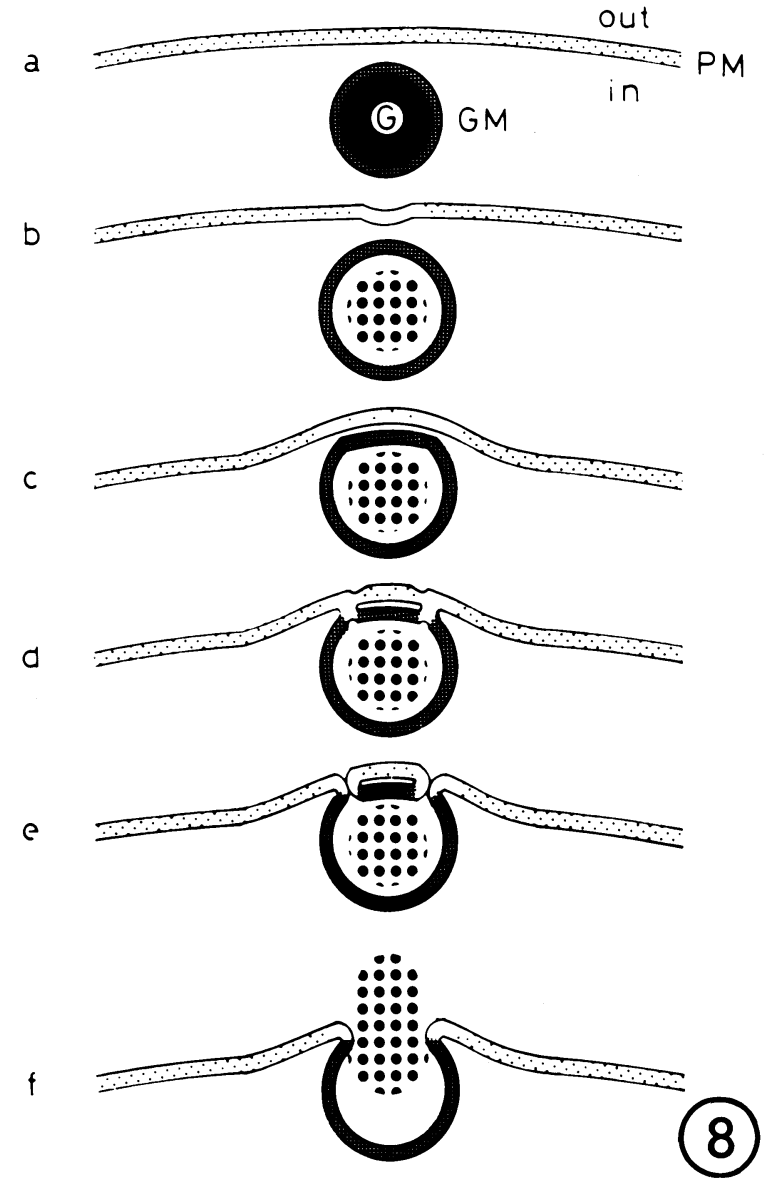

Fig. 8. A hypothetical model for the reorganization of cholesterol during degranulation that involves membrane fusion in the mast cell. The small black dots represent the cholesterol molecules in the plasma and granule membranes. (a) In the resting cell, the cholesterol molecules of the membrane are distributed homogeneously in the plasma and granule membranes, but their density is higher in the latter. (b) Initial stage of the degranulation process; small depressions appear on the degranulation process; small depressions appear on the plasma membrane where cholesterol rearrangement takes place. (c) The swollen granule underneath the depression nears the plasma membrane and produces a bulge from which cholesterol molecules are expelled, probably by lateral movement. (d) Fusion between the two membranes occurs at the bulge where cholesterol has been depleted. (e) A disk-like membrane vesicle is formed when fusion is complete. (f) In the final stage of fusion, this disk-like membrane vesicle is released due to internal pressure within the secretory granule, and the contents of the granule then are discharged into the extracellular space. PM: plasma membrane, GM: granule membrane, G: granule. 


\section{DISCUSSION}

Filipin binds to $3-\beta$-hydroxysterols to form filipin-sterol complexes which are visible as protuberances or pits. in freeze-fracture replicas In unfixed cells, filipin-cholesterol complexes may induce the rearrangement of IMPs, and these complexes and IMPs might move laterally along the membrane plane. However, their distribution is not affected when cells are incubated with filipin during fixation or following fixation with glutaraldehyde (23). Using this cytochemical technique combined with freeze-fracture and thin section electron microscopy, we analyzed the alterations in the distribution of cholesterol molecules during membrane fusion at early times during exocytosis in rat peritoneal mast cells.

Our results show that the filipin-cholesterol complexes were distributed evenly in resting mast cell membranes, and that the granule membrane was more densely labelled with filipin than the plasma membrane. This phenomenon has been reported by other investigators (21). When cells were stimulated with compound 48/80, disappearance of the filipin-cholesterol complexes took place at the small depressions. A similar observation was made by Orci et al. (21) in their study of mast cells.

By contrast, the altered granule membrane underlying the bulges in the plasma membrane showed homogenous distribution of the filipin-cholesterol complexes. Following formation of the circular depressions free of these complexes, folding of the plasma membrane took place around the depressions in the bulge areas (as a local catastrophe) where part of the peripheral granule membrane had fused with the plasma membrane. Filipin-cholesterol complexes were expelled completely at the folding of the plasma membrane forming circles. As also reported by others $(1,28)$ thin sections showed apposition and fusion between the altered granule membrane and plasma membrane. We assume that these bulges, where no complexes were observed, result in the formation of cap-like membrane vesicles. The cap subsequently opens, and the granule's contents are released to the extracellular milieu. Irregularly shaped circular openings were frequent on the cell surface viewed by scanning micrography. Deep cavities below the openings were the result of the fusion of the periphery of the granule membrane with the plasma membrane of the mast cell. These depressions were frequently seen in thin section and freeze-fracture images. Filipin-cholesterol complexes decreased markedly at the neck of the opening where the plasma and altered granule membranes fused. Several stages in the sequence of membrane fusion during exocytosis were observed in our study.

Some freeze-fracture electron microscope observations $(8,19,21)$ have indicated that IMPs are absent from fusion sites in stimulated mast cells. However, no clearing of IMPs during membrane fusion on exocytosis was detected in our study. Similar results have been obtained by quick-freezing mast cells (6). In addition, Friend et al. (11) reported that the initial fusion of the acrosomal and plasmalemma in guinea pig sperm was not associated with the rearrangement of IMPs. These results support the suggestion that the clearing of IMPs from the fusion site may not always occur.

A hypothetical model is proposed for the reorganization of cholesterol molecules during fusion between the two membranes of the mast cell. The distribution of cholesterol molecules in the resting mast cell membrane is homogeneous, but since the granule membrane is more densely covered with filipin-cholesterol complexes than is the plasma membrane, it probably has a higher cholesterol content (Fig. 8a). The earliest redistribution of cholesterol molecules in stimulated cells appears at small depressions in the plasma membrane which are devoid of protuberances or pits; the 
altered peripheral granule membrane shows an even distribution of cholesterol molecules. It has been claimed that cholesterol molecules are reorganized at the site of initial fusion between the acrosome and plasmalemma in guinea pig serpm (11). Chandler et al. (6) demonstrated a pocket-like invagination formed by sequential fusion of the granule membrane with the plasma membrane as an initial event during exocytosis in mast cells. According to their interpretation, reorganization of cholestrol molecules occurs first at the small depression, which is the contact site between the plasma membrane and the underlying peripheral granule membrane (Fig. 8b). This implies that the altered granule membrane may approach the plasma membrane and gradually produce bulges at which time cholesterol molecules are expelled from this bulging region of the plasma membrane. The altered granules approach just beneath the bulge of the plasma membrane (Fig. 8c), then apposition and fusion of the plasma membrane and the peripheral granule membrane take place at the bulge where cholesterol molecules have been depleted. Fusion of the granule membrane with the plasma membrane then takes place at the circular brige (Fig. 8d) and results in the formation of a cap-like membrane vesicle, which consists of the granule membrane and the plasma membrane, when membarne fusion is complete (Fig. 8e). As the final stage in the fusion process, the cap-like membrane vesicle is released due to an increase in the internal pressure within the secretory granule, and the contents of the granule are discharged into the extracellular space. Even after degranulation, the circular membrane portion of the open neck, the site of fusion of the plasma and granule membranes, still lacks cholesterol molecules (Fig. 8f). Cholesterol molecules probably are reorganized at fusion sites as shown in the model during early exocytosis in rat mast cells. Orci et al. (21), however, have suggested that the absence of cholesterol molecules is not necessary for membrane fusion during exocytosis in rat mast cells as revealed by their freeze-fracture micrographs. Their different results may be due to the fact that their mast cells were stimulated for long periods and or were treated with higher concentrations of filipin than in our investigation. The coated pits of the fibroblasts show that filipin-cholesterol complexes have disappeared completely from the fusion sites, evidence of the induction of a low ratio of cholesterol to phospholipid (20). It is impossible to examine the cholesterol to phospholipid ratio of mast cells at the fusion sites because these focal areas cannot be isolated from the plasma membrane; however, the disappearance of the filipin-cholesterol complexes from the fusion sites suggests that the deletion of cholesterol molecules, or at least a significant reduction in the cholesterol to phospholipid ratio, occurs at a step during the degranulation of mast cells. If cholesterol molecules move laterally from the focal site to the surrounding membrane, the surrounding areas of the membrane should be heavily labelled with filipin, but no such alteration was observed. Deletion of cholesterol from the bilayer membrane is known to effect membrane fluidity (9). Therefore, it is probable that the cholesterol-free areas at the fusion sites, promote a condition of the membrane which is ideal for interaction between the peripheral granule and plasma membranes. The results of our study are evidence, that cholesterol molecules play a fundamental role in membrane fusion during the early stages of exocytosis in rat peritoneal mast cells.

Acknowledgements. We thank Dr. J.E. Grady for the supply of filipin, Dr. Y. Kitajima for his helpful discussions, and Dr. G.T. Cole for his critical reading of the manuscript. 


\section{REFERENCES}

1. Anderson, P., S.A. Slorach and B. Uvnäs. Sequential exocytosis of storage granules during antigen-induced histamine release from sensitized rat mast cells in vitro. Acta Physiol. Scand. 88, 359-372, 1973

2. Bloom, C.D. and Ö. Haegermark. A study on morphological changes and histamine release induced by compound 48/80 in rat peritoneal mast cells. Exp. Cell Res. 40, 637-654, 1965

3. Bloom, G.D., and N. Chakravarty. Time course of anaphylactic histamine release and morphological changes in rat peritoneal mast cells. Acta Physiol. Scand. 78, 410-419, 1970

4. Burwen, S.J., and B.H. SATIR. A freeze-fracture study of early membrane events during mast cell secretion. J. Cell Biol. 73, 660-671, 1977

5. Chandler, D.E. and J.E. Heuser. Membrane fusion during secretion. Cortical granule exocytosis in sea urchin egg as studied by quick-freezing and freeze-fracture. J. Cell Biol. 83, 91-108, 1979

6. Chandler, D.E. and J.E. Heuser. Arrest of membrane fusion events in mast cells by quickfreezing. J. Cell Biol. 86, 666-674, 1980

7. ChI, E.Y., D. LAgUnOfF, and J.K. Koehler. Electron microscopy of freeze-fractured rat peritoneal mast cells. J. Ultrastruct. Res. 51, 46-54, 1975

8. Chi, E.Y., D. Lagunoff and J.K. Koehler. Freeze-etch study of mast cell secretion. Proc. Natl. Acad. Sci. U.S.A. 73, 2823-2827, 1976

9. Demel, R.A., and B. De KruiJfF. The function of sterols in membrane. Biochim. Biophys. Acta 457, 109-132, 1976

10. Elias, P.M., D.S. Friend and J. Goerke. Membrane sterol heterogeneity. Freeze-fracture detection with saponins and filipin. J. Histochem. Cytochem. 27, 1247-1260, 1979

11. Friend, D.S. and P.M. EliAS. Heterogeneity of filipin-sterol complexes in the guinea pig sperm plasma membrane. J. Cell Biol. 79, 216a, 1978

12. Gruda, I., P. Nadeau, J. Brajtburg and G. Medoff. Application of differential spectra in the ultraviolet-visible region to study the formation of amphotericin B-sterol complexes. Biochim. Biophys. Acta 602, 260-268, 1980

13. Kagayama, M. and W.W. Douglas. Electron microscope evidence of calcium-induced exocytosis in mast cells treated with compound $48 / 80$ or the ionophores A 23187 and X 537A. J. Cell Biol. 62, 519-526, 1974

14. Kessler, S. and C. KuHN. Scanning electron microscopy of mast cell degranulation. Lab. Invest. 32, 71-77, 1975

15. KInSky, S.C. Antibiotic interaction with model membranes. Annu. Rev. Pharmacol. 10, 119-142, 1970

16. Kitajima. Y., T. SekiYa and Y. Nozawa. Freeze-fracture ultrastructural alterations induced by filipin, pimaricin, nystatin and amphotericin B in the plasma membranes of Epidermophyton, Saccharomyces and red blood cells. A proposal of models for polyene ergosterol complexinduced membrane lesions. Biochim. Biophys. Acta 455, 452-465, 1976

17. Lagunoff, D. The mechanism of histamine release from mast cells. Biochem. Pharmac. 21, 1889-1896, 1972

18. Lagunoff, D. Membrane fusion during mast cell secretion. J. Cell Biol. 57, 252-259, 1973

19. Lawson, D., M.R. Raff, B. Gomperts, C. Fewtrell and N.B. Gilula. Molecular events during membrane fusion. A study of exocytosis in rat peritoneal mast cells. J. Cell Biol. 72, 242-259, 1977

20. Montesano, R., A. Perrelet, P. Vassalli and L. Orci. Absence of filipin-sterol complexes from large coated pits on the surface of culture cells. Proc. Natl. Acad. Sci. U.S.A. 76, 63916395,1979

21. Montesano, R., P. Vassalli, A. Perrelet and L. Orci. Distribution of filipin-cholesterol complexes at sites of exocytosis. A freeze-fracture study of degranulating mast cells. Cell Biol.: International Reports 4, 975-984, 1980

22. ORCI, L., R. Montesano and D. Brown. Heterogeneity of totad bladder granular cell luminal membranes. Distribution of filipin-sterol complexes in freeze-fracture. Biochim. Biophys. Acta 
601, 443-452, 1980

23. Robinson, J.M. and J. KARnovSKy. Evaluation of the polyene antibiotic filipin as a cytochemical probe for membrane cholesterol. J. Histochem. Cytochem. 28, 161-168, 1980

24. RöHLICH, P., P. ANDERSON and B. UvNÄS. Electron microscope observations on compound 48/80-induced degranulation in rat mast cells. J. Cell Biol. 51, 465-483, 1971

25. Sekiya, T., Y. Kitajima and Y. Nozawa. Effects of lipid-phase separation on the filipin action of ergosterol-replaced Tetrahymena cell. As studied by freeze-fracture electron microscopy. Biochim. Biophys. Acta 550, 269-278, 1979

26. Singleton, E.M. and S.L. Clark. The response of mast cells to compound 48/80 studied with the electron microscope. Lab. Invest. 14, 1744-1763, 1965

27. SpUrR, A.R. A low-viscosity epoxy resin-embedding medium for electron microscopy. $J$. Ultrastruct. Res. 26, 31-43, 1969

28. Sullivan, T.J., K.L. Parker, W. Stenson and C.W. Parker. Modulation of cyclic AMP in purified rat mast cells. 1. Responses to pharmacologic, metabolic, and physical stimuli. $J$. Immunol. 114, 1473-1479, 1975

29. Tanaka, T., P. De Camilli and J. Meldolesi. Membrane interactions between secretion granules and plasmalemma in three exocrine grands. J. Cell Biol. 84, 438-453, 1980

30. Tillack, T.W. and S.C. Kinsky. A freeze-etch study of the effects of filipin on liposomes and human erythrocyte membranes. Biochim. Biophys. Acta 323, 43-54, 1973

(Received for publication, August 11, 1981) 